\title{
Rancang Bangun Aplikasi Website Administrasi Kerja Praktek Dan Tugas Akhir Mahasiswa Program Studi Teknik Informatika Universitas Sam Ratulangi
}

\author{
Youri J. B. Toreh, Steven R. Sentinuwo, Alwin M. Sambul \\ Teknik Informatika Universitas Sam Ratulangi. Manado, Indonesia \\ torehyouri@gmail.com,steven@unsrat.ac.id, asambul@unsrat.ac.id
}

\begin{abstract}
Abstrak - Kerja Praktek dan Tugas Akhir merupakan mata kuliah wajib bagi mahasiswa program Studi Teknik Informatika Universitas Sam Ratulangi sebagai syarat kelulusan sarjana. Semua proses administrasi pada Kerja Praktek dan Tugas Akhir masih dilakukan secara manual, proses verifikasi dan tanda tangan berkas sering kali terkendala dosen dan pimpinan tidak berada di kampus sehingga proses administrasi menjadi lebih lama.

Menggunakan metodologi pengembangan Sistem Perangkat Lunak Rapid Application Development (RAD) peneliti membuat Rancang Bangun Aplikasi Website ini untuk memecahkan masalah tersebut. Sistem juga dibangun menggunakan framework PHP Codeigniter yang di kembangkan untuk memudahkan dalam mengembangkan aplikasi dengan struktur file source code-nya menggunakan pendekatan ModelView-Controller (MVC) dan pemrograman berorientasi objek dengan tambahan framework CSS bootstrap yang memudahkan pengembang untuk membangun website yang menarik dan responsif. Hasil dari penelitian ini adalah sebuah aplikasi website administrasi Kerja Praktek dan Tugas Akhir di Program Studi Teknik Informatika UNSRAT.
\end{abstract}

Kata kunci: Administrasi, Website, RAD, Mahasiswa

\section{PENDAHULUAN}

Aplikasi website saat ini berkembang sangat pesat, hal ini disebabkan oleh beberapa faktor salah satunya adalah perkembangan teknologi internet yang sangat pesat. Begitupun dengan kebutuhan manusia yang meningkat dalam pengolahan data, mengharuskan setiap instansi membangun sebuah sistem yang berbasis komputer baik secara online maupun offline, salah satu yang bisa dibangun adalah sebuah aplikasi website. Tujuan dibangunnya aplikasi website antara lain untuk memudahkan dalam mengkases dan melakukan pengolahan data lainnya. Adanya sebuah aplikasi website dapat meningkatkan kinerja maksimal terhadap suatu instansi serta dapat menerapkan perkembangan teknologi yang semakin maju

Program Studi Teknik Informatika Universitas Sam Ratulangi merupakan salah satu program studi tingkat sarjana (S1) yang mewajibkan setiap mahasiswanya untuk menyelesaikan sebuah Tugas Akhir (TA) sebelum berhasil mendapatkan gelar sarjana. Selain Tugas Akhir, mahasiswa Teknik Informatika Unsrat juga harus menyelesaikan mata kuliah Kerja Praktek (KP). mahasiswa yang mengikuti mata kuliah Tugas Akhir dan Kerja Praktek wajib melakukan pendaftaran atau mengurus administrasi terlebih dahulu untuk keperluan surat-surat yang dibutuhkan untuk memulai, melaksanakan dan menyelesaikan mata kuliah ini. Pendaftaran tersebut diverifikasi oleh dosen staf pegawai yang bertanggung jawab dibagian tersebut. Sampai saat ini proses administrasi masih di lakukan secara manual sehingga membutuhkan waktu yang relatif lama sehingga tak jarang mendapatkan keluhan dari mahasiswa.

Dengan adanya teknologi komputer dan juga Unsrat yang sudah memiliki jaringan sendiri maka dapat dibangun suatu sistem aplikasi website administrasi dimana pengolahan data pendaftaran Kerja Praktek dan Tugas Akhir dapat dilakukan secara online tanpa harus berada di kampus sehingga proses administrasi baik Kerja Praktek maupun Tugas Akhir akan lebih mudah dan lebih cepat sehingga tidak memakan banyak waktu dan mahasiswa dapat melakukan proses administrasi di manapun dan kapanpun.

Berdasarkan latar belakang masalah yang telah penulis uraikan diatas maka penulis dalam pembuatan aplikasi ini mengambil judul Rancang Bangun Aplikasi Website Administrasi Kerja Praktek dan 
Tugas Akhir Mahasiswa Program Studi Teknik Informatika UNSRAT.

\section{LANDASAN TEORI}

\section{A. Rancang Bangun}

Jogiyanto mendefinisikan rancang bangun adalah tahap dari setelah analisis dari siklus pengembangan sistem yang merupakan pendefinisian dari kebutuhankebutuhan fungsional, serta menggambarkan bagaimana suatu sistem dibentuk yang dapat berupa penggambaran, perencanaan dan pembuatan sketsa atau pengaturan dari beberapa elemen yang terpisah ke dalam satu kesatuan yang utuh dan berfungsi, termasuk menyangkut mengkonfigurasikan dari komponen-komponen perangkat keras dan perangkat lunak dari suatu sistem. ${ }^{[3]}$

\section{B. Administrasi}

Drs. Soewarno Hardayaningrat mendefinisikan administrasi adalah kegiatan catat-mencatat, suratmenyurat, pembukuan ringan, ketik-mengetik, agenda dan sebagainya yang bersifat teknis ketatausahaan. ${ }^{[2]}$

\section{Aplikasi Web}

Aplikasi Web dapat dibagi menjadi dua jenis yaitu aplikasi web statis dan dinamis. Web statis dibentuk dengan menggunakan HTML(Hypertext Markup Languange). HTML sendiri merupakan file teks murni yanng dapat dibuat dengan teks editor sembarang yaitu dikena sebagai web page atau dokumen yang disajikan dalam web browser ${ }^{[5]}$ Kekurangan aplikasi seperti ini terletak pada keharusan untuk memelihara program secara terus menerus untuk mengikuti setiap perkembangan yang terjadi.

Web dinamis merupakan sebuah website yang menyediakan konten atau isi yang selalu berubah-ubah setiap saat. Aplikasi web dapat dikoneksikan ke database seperti database MYSQL. MYSQL merupakan software sistem manajemen database (Database Management System - DBMS) yang sangat populer dikalangan pemrograman web, terutama di lingkungan linux dengan menggunakan skrip dan ped. ${ }^{[7]}$ Dengan mengkoneksikan ke database, perubahan informasi dapat dilakukan oleh operator atau yang bertanggung jawab terhadap kemutakhiran data, dan tidak menjadi tanggung jawab pemrograman. ${ }^{[2]}$

Pengembangan aplikasi web juga dapat dilakukan menggunakan framework PHP (Personal Home Page). PHP sendiri adalah bahasa pemrograman yang berbentuk script yang diletakkan didalam web server. ${ }^{[6]}$ Salah satu framework php yang dapat digunakan adalah codeigniter yang dapat membantu mempercepat developer dalam pengembangan aplikasi web berbasis PHP dibandingkan jika menulis semua kode program dari awal. Codeigniter menyediakan banyak library untuk mengerjakan tugas-tugas yang umumnya ada pada sebuah aplikasi berbasis web. Selain itu, struktur dan susunan logis dari codeigniter membuat aplikasi yang dibuat menjadi semakin teratur dan rapi. ${ }^{[1]}$

\section{Tugas Akhir}

Tugas akhir merupakan sebagian persyaratan yang harus dipenuhi oleh mahasiswa untuk mendapatkan gelar sarjana. Proses penyelesaian dilakukan dengan berpedoman kepada kaidah yang berlaku. Dalam pelaksanaanya mahasiswa dibimbing oleh tim pembimbing yang bertugas memberikan arahan dan masukkan kepada mahasiswa agar tugaas akhir yang dihasilkan memenuhi kriteria dan persyaratan penulisan baku. ${ }^{[10]}$

\section{E. Kerja Praktek}

Guna mendapatkan gambaran lebih nyata di lapangan dan menilai aspek aplikasi teori-teori yang pernah dipelajari di kuliah kelas maupun laboratorium, diselenggarakan kegiatan-kegiatan akademik lainnya seperti kerja praktek. Mahasiswa yang akan mengikuti kegiatan ini sudah memiliki pengetahuan yang cukup. Penyelenggaraan kerja praktek diserahkan kepada masing-masing Jurusan, sedangkan Kuliah Kerja Nyata diatur oleh Universitas. Beberapa mata kuliah melaksanakan praktek kerja lapangan dimana pengaturannya diserahkan kepada dosen pengampu mata kuliah yang bersangkutan dengan dikoordinasi oleh Jurusan yang bersangkutan. ${ }^{[8]}$

\section{METODOLOGI PENGEMBANGAN}

Adapun metode pengembangan sistem yang digunakan pada penelitian ini yaitu metode Rapid Application Development (RAD) yang merupakan sebuah strategi pengembangan sistem dimana menekan kecepatan pengembangan melalui keterlibatan user ekstensif dalam kecepatan, iterative (berulang) dan incrumental Construction dari serangkaian fungsi dari prototype sebuah sistem yang pada akhirnmya akan mengalami perubahan secara bertahap menuju sistem akhir. Gambar 1 menjelaskan alur metodologi pengembangan Rapid Application Development (RAD). 


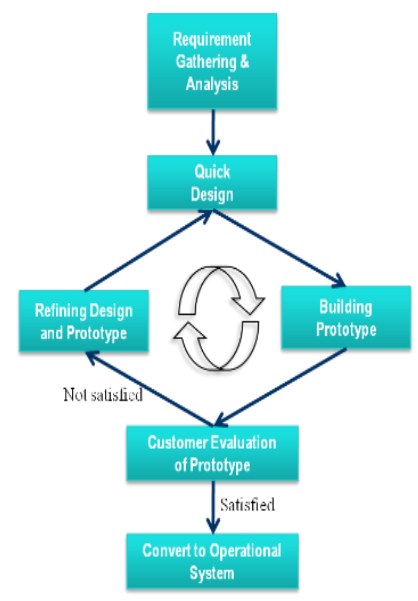

Gambar 1. Metode Pengembangan Perangkat Lunak RAD

Ada 4 tahapan yang harus dilakukan pada metodologi RAD yaitu analisis persyaratan, analisis modelling, desain modelling dan konstruksi :

\section{Analisis Persyaratan}

Tahap ini bertujuan untuk mengidentifikasi kebutuhan pengguna, spesifikasi sistem melalui observasi dan pengumpulan data yang dilakukan terhadap stakeholders, sehingga aplikasi yang akan dibuat akan sesuai dengan yang dibutuhkan oleh pengguna.

2. Analisis Modeling

Tujuan dari fase analisis modelling adalah menganalisa semua kegiatan dalam arsitektur sistem secara keseluruhan dengan melibatkan identifikasi dan deskripsi abstraksi sistem perangkat lunak yang mendasar dan hubunganhubungannya. Selain itu, analisis modelling juga bertujuan untuk meningkatkan pemahaman terhadap permasalahan tanpa mempertimbangkan solusi teknis. Hasil akhir dari analisis modelling yaitu diagram model logis sistem yang sedang berjalan, diantaranya use case diagram, acticity diagrams, class diagram, dan sequence diagram.

\section{Desain Modelling}

Tujuan dari fase desain modeling yaitu melakukan perancangan sistem berdasarkan analisis yang telah dilakukan sebelumnya. Tahap analisis dan desain mengalami perulangan hingga diperoleh rancangan sistem yang benar-benar memenuhi kebutuhan. Selain itu, fase ini juga bertujuan untuk memberikan spesifikasi yang jelas dan lengkap kepada programmer dan teknisi. Hasil akhir dari fase ini yaitu basis data, antarmuka, dan spesifikasi desain.

\section{Konstruksi}

Tujuan dari fase konstruksi adalah untuk menunjukkan platform, hardware dan software yang digunakan serta batasan dalam implementasi, serta menguji performansi prototipe perangkat lunak yang telah dibangun agar dapat diketahui apakah prototipe tersebut telah sesuai dengan spesifikasi analisis dan perancangan yang telah diidentifikasi sebelumnya. $^{[9]}$

\section{HASIL DAN PEMBAHASAN}

\section{A. Tahap Analisis Persyaratan}

Tahap ini mengidentifikasi layanan, batasan dan obyektifitas dari sistem pengumpulan data yang dilakukan, selain itu, fase analisis persyarata juga bertujuan untuk mengidentifikasi persyaratan pengguna dan sistem.

\section{Komunikasi dan Perencanaan}

1. Manajemen Resiko

Dalam setiap proyek, tentu saja diperhadapkan denga berbagai macam resiko, berikut adalah resikoresiko yang mungkin terjadi dalam pengembanga aplikasi.

Tabel 1. Manajemen Resiko

\begin{tabular}{|l|l|l|l|l|}
\hline $\begin{array}{l}\text { N } \\
\text { o. }\end{array}$ & Risk & Contigency & Cause & Effect \\
\hline 1. & $\begin{array}{l}\text { Perubahan } \\
\text { jadwal. }\end{array}$ & $\begin{array}{l}\text { Penyesuaia } \\
\text { n jadwal } \\
\text { kembali. }\end{array}$ & $\begin{array}{l}\text { Keterlambat } \\
\text { an. }\end{array}$ & $\begin{array}{l}\text { Waktu } \\
\text { lebih lama. }\end{array}$ \\
\hline 2. & $\begin{array}{l}\text { Kesalahan } \\
\text { pemrogram } \\
\text { an. }\end{array}$ & $\begin{array}{l}\text { Perbaikan } \\
\text { kesalahan } \\
\text { pemrogram } \\
\text { an. }\end{array}$ & $\begin{array}{l}\text { Ketidak- } \\
\text { telitian. }\end{array}$ & $\begin{array}{l}\text { Keterlamba } \\
\text { tan dan } \\
\text { performa } \\
\text { yang tidak } \\
\text { maksimal. }\end{array}$ \\
\hline 3. & $\begin{array}{l}\text { Perubahan } \\
\text { persyaratan } \\
\text { pengguna. }\end{array}$ & $\begin{array}{l}\text { Pemrogram } \\
\text { an kembali. }\end{array}$ & $\begin{array}{l}\text { Keinginan } \\
\text { user yang } \\
\text { berubah- } \\
\text { ubah. }\end{array}$ & $\begin{array}{l}\text { Keterlamba } \\
\text { tan dan } \\
\text { performa } \\
\text { program } \\
\text { yang tidak } \\
\text { maksimal. }\end{array}$ \\
\hline 4. & $\begin{array}{l}\text { Kesalahan } \\
\text { analisis } \\
\text { sistem. }\end{array}$ & $\begin{array}{l}\text { Analisis } \\
\text { kembali } \\
\text { dan terjadi } \\
\text { perombakk } \\
\text { an desain. }\end{array}$ & $\begin{array}{l}\text { Keinginan } \\
\text { user yang } \\
\text { tidak } \\
\text { teridentifika } \\
\text { si dengan } \\
\text { baik. }\end{array}$ & $\begin{array}{l}\text { Perubahan } \\
\text { fitur. }\end{array}$ \\
\hline
\end{tabular}


Tabel 2. Manajemen Perubahan

\begin{tabular}{|l|l|l|l|l|}
\hline No & $\begin{array}{l}\text { Perubah } \\
\text { an yang } \\
\text { dilakuka } \\
\text { n }\end{array}$ & $\begin{array}{l}\text { Perencanaa } \\
\text { n awal }\end{array}$ & Penyebab & Akibat \\
\hline 1. & $\begin{array}{l}\text { Menyedi } \\
\text { akan fitur } \\
\text { asistensi } \\
\text { kerja } \\
\text { praktek }\end{array}$ & $\begin{array}{l}\text { Tidak } \\
\text { menyediakan } \\
\text { fitur asistensi } \\
\text { kerja praktek }\end{array}$ & $\begin{array}{l}\text { permintaa } \\
\text { pihak dari } \\
\text { pengguna }\end{array}$ & $\begin{array}{l}\text { Menambah } \\
\text { fitur asistensi } \\
\text { kerja prakek }\end{array}$ \\
\hline 2. & $\begin{array}{l}\text { Menamb } \\
\text { ah widget } \\
\text { aktifitas } \\
\text { pada } \\
\text { halaman } \\
\text { mahaswa } \\
\text { si }\end{array}$ & $\begin{array}{l}\text { Tidak } \\
\text { menyediakan } \\
\text { aktifitas } \\
\text { mahasiswa }\end{array}$ & $\begin{array}{l}\text { Permintaa } \\
\text { nihak } \\
\text { dari } \\
\text { pengguna }\end{array}$ & $\begin{array}{l}\text { Menambah } \\
\text { widget } \\
\text { aktifitas }\end{array}$ \\
\hline
\end{tabular}

\section{B. Tahap Analisis Modelling}

Daftar Aktor dapat dilihat pada tabel 3

Tabel 3. Daftar Aktor Beserta Tugas dan Tanggung Jawabnya

\begin{tabular}{|c|c|}
\hline Stakeholders & Tugas dan Tanggung Jawab \\
\hline $\begin{array}{l}\text { Koordinator } \\
\text { Kerja Praktek }\end{array}$ & $\begin{array}{l}\text { Menyetujui permohon kerja praktek, } \\
\text { menentukan calon dosen pembimbing kerja } \\
\text { prakek mahasiswa }\end{array}$ \\
\hline $\begin{array}{l}\text { Staf } \\
\text { Admnistrasi }\end{array}$ & $\begin{array}{l}\text { Melihat daftar pedaftaran kerja praktek } \\
\text { mahasiswa, menyetujui pendaftaran kerja } \\
\text { praktek, menginput calon dosen pembimbing }\end{array}$ \\
\hline Dosen & $\begin{array}{l}\text { Melihat daftar mahasiswa bimbingan, } \\
\text { menyetujui calon mahasiswa bimbingan }\end{array}$ \\
\hline Mahasiswa & $\begin{array}{l}\text { Mendaftar kerja praktek, proposal, SK 1, SK 2, } \\
\text { SK } 3\end{array}$ \\
\hline $\begin{array}{l}\text { Ketua } \\
\text { Jurusan } \\
\text { Elektro }\end{array}$ & Verifikasi berkas SK 1, SK 2, SK 3 \\
\hline $\begin{array}{l}\text { Kasubag } \\
\text { Akademik }\end{array}$ & Verifikasi berkas SK 1, SK 2, SK 3 \\
\hline WD 1 & Verifikasi berkas SK 1, SK 2, SK 3 \\
\hline Staf WD 1 & Cetak SK 1, SK 2, SK 3 \\
\hline Dekan & $\begin{array}{l}\text { Lihat Data Pengurusan Berkas SK 1, SK 2, SK } \\
3\end{array}$ \\
\hline
\end{tabular}

\section{Tahap Desain Modelling}

Use case diagram menggambarkan hubungan antara aktor dan sistem. Adapun aktor dalam dalam website ini yaitu: koordinator $\mathrm{kp}$, dosen, mahasiswa, kajur, kasubag, pd1, staf administrasi dan dekan.

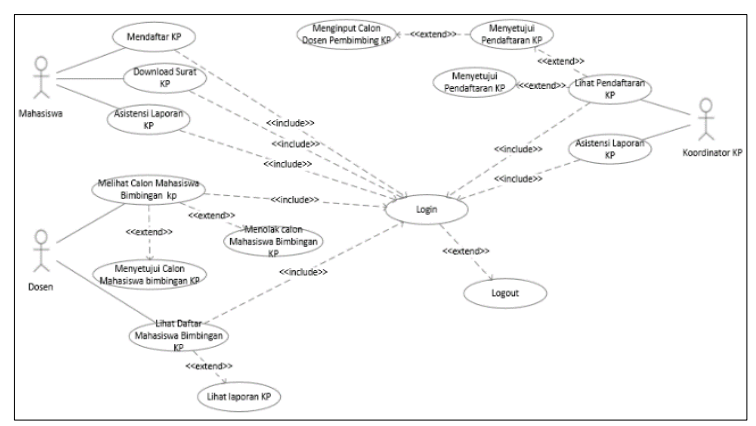

Gambar 2. Use Case Diagram KP

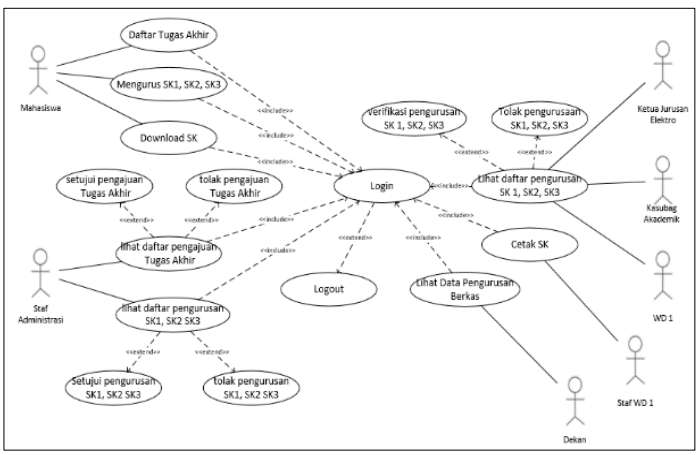

Gambar 3. Use Case Diagram Tugas Akhir

\section{Tahap Konstruksi}

\section{Implementasi Antar Muka}

Gambar 3 merupakan tampilan login,, user akan memasukkan username dan password, sistem akan membaca tipe user yang melakukan login sesuai dengan username yang di masukkan.

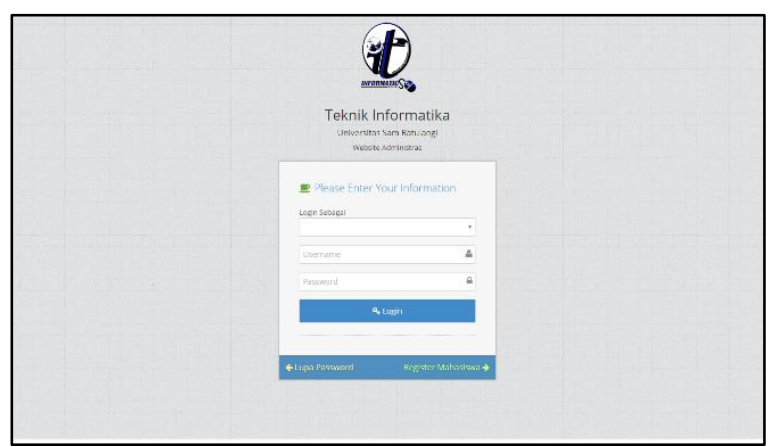

Gambar 3. Halaman Login

Gambar 4 merupakan tampilan halaman mahasiswa. Pada hamalana mahaiswa akan menampilkan tabel pesan, tabel log aktivitas, edit profil, dan download. Pada tabel pesan akan menampilkan pesan masuk baik yang sudah di baca maupun yang belum di baca, pesan berupa pemberitahuan mengenai pendaftaran kerja praktek, 
pengurusan berkas tugas akhir, dan pesan dari dosen pembimbing.

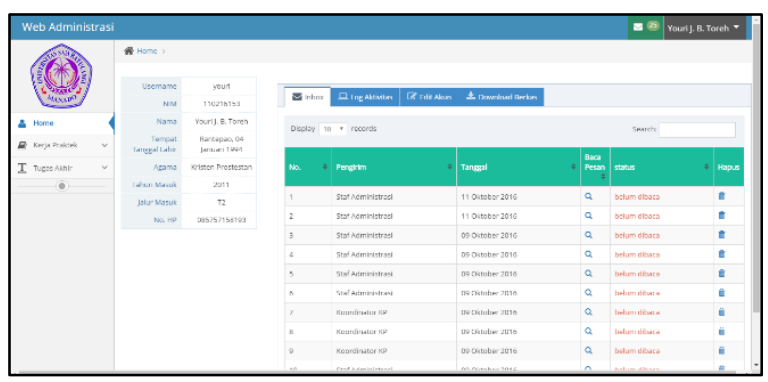

Gambar 4. Halaman Mahasiswa

Gambar 5 merupakan tampilan halaman dosen. Pada halaman dosen terdapat halaman yaitu halaman daftar calon mahasiswa bimbingan kerja praktek dan halaman mahasiswa bimbingan. Pada halaman daftar calon mahasiswa bimbingan akan menampilkan tabel yang berisi daftar calon mahasiswa yang sebelumnya telah di input oleh koordinator kp.

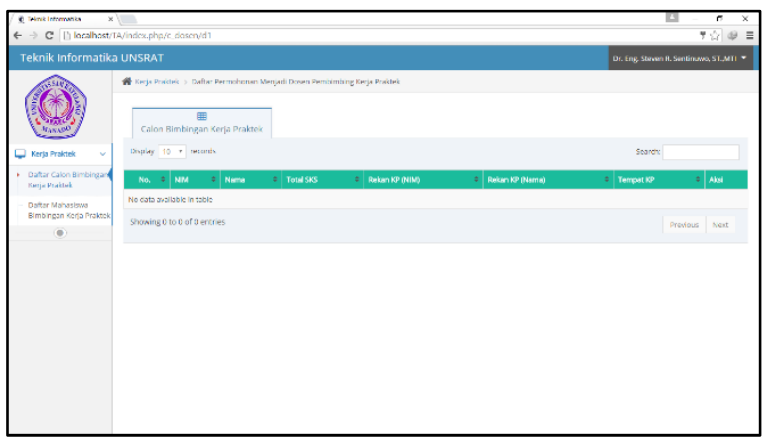

Gambar 5. Halaman Dosen

Gambar 6 merupakan tampilan halaman koordinator $\mathrm{kp}$ yang menampilkan tabel daftar pendaftaran kerja praktek mahasiswa. koordinator akan menyetujui atau menolak pendaftaran kerja praktek pada halaman ini.

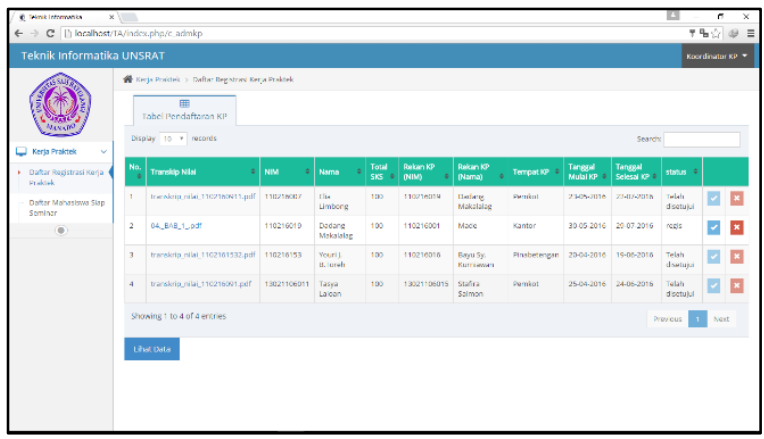

Gambar 6. Halaman Koordinator KP

Gambar 7 merupakan tampilan halaman staf adminstrasi, staf yang akan menindaklanjuti pendaftaran tugas akhir mahasiswa dan juga sk 1 , sk 2, dan sk 3

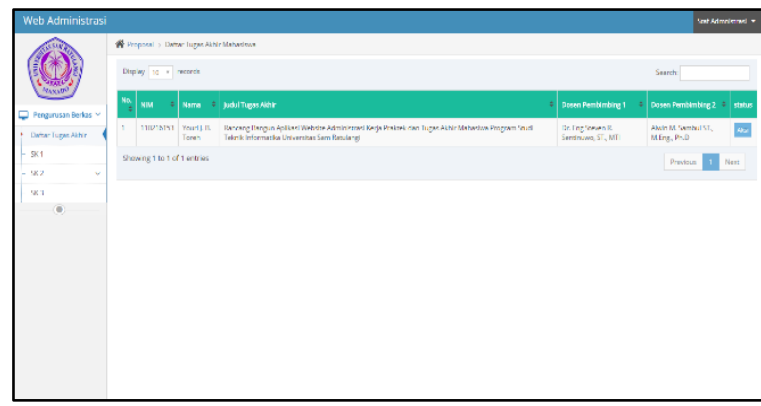

Gambar 7. Halaman Staf Adminstrasi

Gambar 8 merupakan halaman dari ketua jurusan, etua jurusan akan menverifikasi berkas sk 1, sk 2 dan sk 3 mahasiswa yang sebelumnya telah disetujui oleh staf adminstrasi. Pada hamalan ini ketua jurusan akan menverifikasi berkas SK 1, SK 2 dan SK 3 mahasiswa

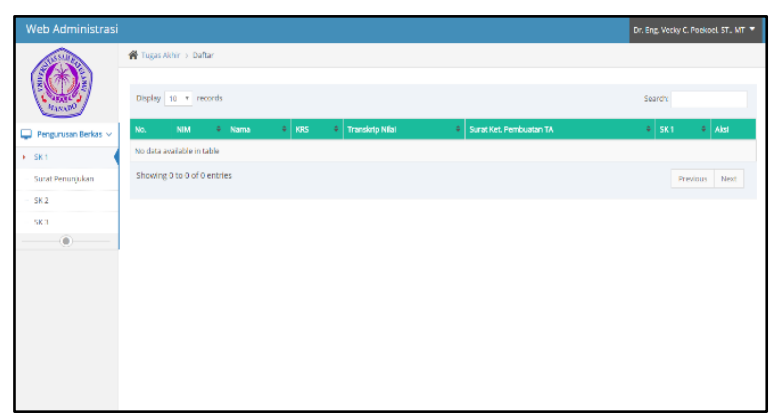

Gambar 8. Halaman Ketua Jurusan

Gambar 9 merupakan tampilan dari halaman kasubag akademik yang akan menampilkan berkas sk mahasiswa yang sebelumnya telah diverifikasi oleh ketua jurusan. Pada hamalan ini Kasubag akademik akan menverifikasi berkas SK 1, SK 2 dan SK 3 mahasiswa.

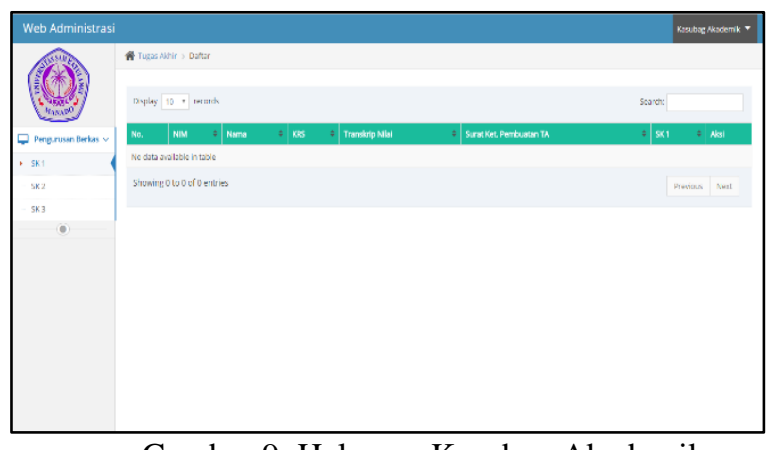

Gambar 9. Halaman Kasubag Akademik

Gambar 10 merupakan tampilan dari halaman wd 1, halaman ini akan menampilkan data berkas sk 1, sk 2, dan sk 3 mahasiswa yang telah diverifikasi oleh kasubag akademik, pada halaman ini WD 1 akan menverifikasi berkas SK 1, SK 2 dan SK 3 mahasiswa. 


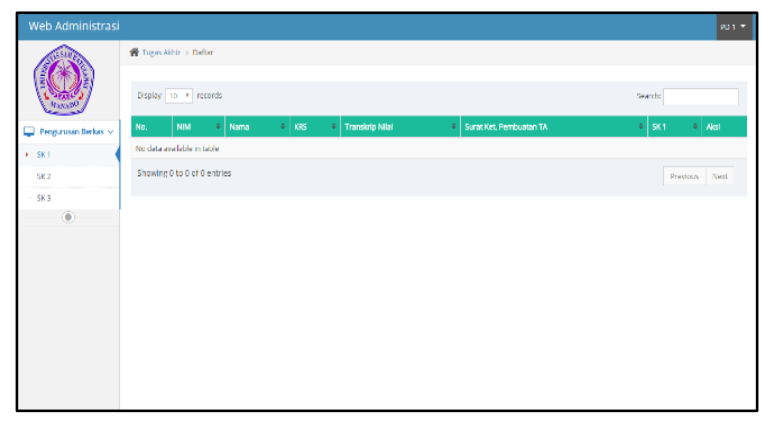

Gambar 10. Halaman WD 1

Gambar 11 merupakan tampilan dari halaman staf wd 1, pada halaman akan ditampilkan daftar pengurusan sk 1, sk 2 dan sk 3 yang telah di verifikasi oleh ketua jurusan, kasubag akademik dan wd 1 dan staf wd 1 akan mencetak sk 1 , sk 2 dan sk 3 mahasiswa untuk nanti di bawah ke dekan untuk di tanda tangani.

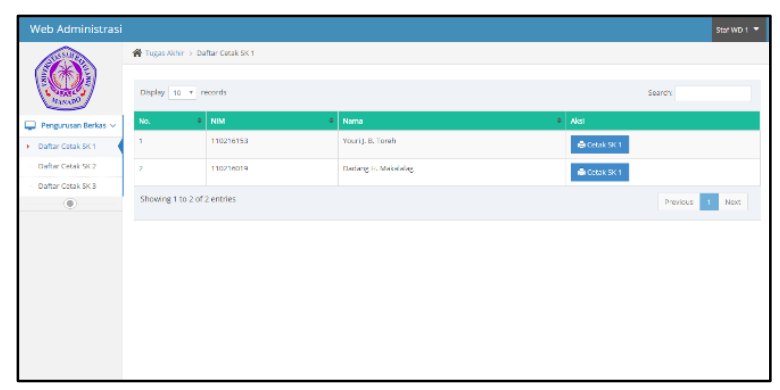

Gambar 11. Halaman Staf WD 1

Gambar 12 merupakan tampilan halaman dekan, pada halaman ini dekan bias melihat perkembangan pengurusan berkas sk 1, sk 2 dan sk 3 mahasiswa

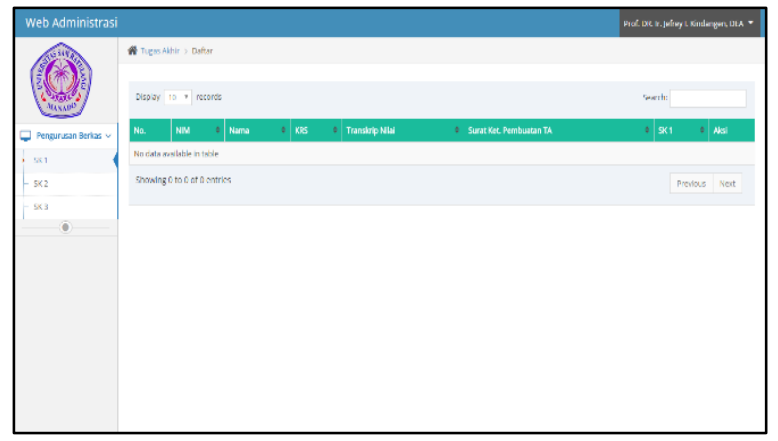

Gambar 12. Halaman Dekan

\section{Pengujian Sistem}

Tabel 4. Pengujian Login

\begin{tabular}{|c|c|c|c|}
\hline No. & Kegiatan & $\begin{array}{c}\text { Hasil yang } \\
\text { diharapkan }\end{array}$ & $\begin{array}{c}\text { Hasil yang } \\
\text { didapat }\end{array}$ \\
\hline 1. & $\begin{array}{l}\text { Login } \\
\text { Mahasiswa } \\
\text { Memasukkan } \\
\text { data log in: } \\
\text { Username: } \\
\text { youri } \\
\text { Password: toreh }\end{array}$ & $\begin{array}{l}\text { Sistem akan } \\
\text { menampilkan } \\
\text { halaman } \\
\text { halaman } \\
\text { mahasiswa } \\
\text { Youri Toreh. }\end{array}$ & $\begin{array}{l}\text { Sistem } \\
\text { menampilkan } \\
\text { halaman } \\
\text { Mahasiswa } \\
\text { Youri Toreh }\end{array}$ \\
\hline 2 & $\begin{array}{l}\text { Login } \\
\text { mahasiswa } \\
\text { Memasukkan } \\
\text { data log in: } \\
\text { Username: } \\
\text { youri } \\
\text { Password: } \\
12345 \\
\end{array}$ & $\begin{array}{l}\text { Tidak dapat } \\
\text { mengakses } \\
\text { halaman } \\
\text { mahasiswa, } \\
\text { memberikan } \\
\text { pesan kesalahan. }\end{array}$ & $\begin{array}{l}\text { Sistem } \\
\text { menampilkan } \\
\text { kembali halaman } \\
\text { login dengan } \\
\text { pesan } \\
\text { kelasalahn. }\end{array}$ \\
\hline 3. & $\begin{array}{l}\text { Login Dosen : } \\
\text { Memasukkan } \\
\text { data log in: } \\
\text { Username: } \\
\text { dosen } 1 \\
\text { Password: } \\
\text { dosen1 } \\
\end{array}$ & $\begin{array}{l}\text { Sistem akan } \\
\text { menampilkan } \\
\text { halaman dosen } 1\end{array}$ & $\begin{array}{l}\text { Sistem } \\
\text { menampilkan } \\
\text { halaman dosen } 1\end{array}$ \\
\hline 4. & $\begin{array}{l}\text { Login dosen : } \\
\text { Memasukkan } \\
\text { data log in: } \\
\text { Username: } \\
\text { dosen } 1 \\
\text { Password: } \\
12344\end{array}$ & $\begin{array}{l}\text { Tidak dapat } \\
\text { mengakses } \\
\text { halaman dosen1, } \\
\text { menampilkan } \\
\text { pesan username } \\
\text { dan/atau } \\
\text { password tidak } \\
\text { cocok. }\end{array}$ & $\begin{array}{l}\text { Sistem } \\
\text { menampilkan } \\
\text { kembali halaman } \\
\text { login dengan } \\
\text { pesan kesalahan. }\end{array}$ \\
\hline
\end{tabular}

Tabel 5. Pengujian Menampilkan Data

\begin{tabular}{|c|c|c|c|}
\hline No. & Kegiatan & $\begin{array}{l}\text { Hasil yang } \\
\text { diharapkan }\end{array}$ & $\begin{array}{c}\text { Hasil yang } \\
\text { didapat }\end{array}$ \\
\hline 1. & $\begin{array}{l}\text { Login sebagai } \\
\text { koordinator } \\
\text { kerja praktek }\end{array}$ & $\begin{array}{l}\text { Sistem akan } \\
\text { menampilkan } \\
\text { halaman } \\
\text { koordinator } \\
\text { kerja praktek. } \\
\text { Dan } \\
\text { menampilkan } \\
\text { data dari } \\
\text { mahasiswa yang } \\
\text { melakukan } \\
\text { pendaftaran } \\
\text { kerja praktek }\end{array}$ & $\begin{array}{l}\text { Sistem } \\
\text { menampilkan } \\
\text { halaman } \\
\text { koordinator } \\
\text { kerja praktek. } \\
\text { Dan } \\
\text { menampilkan } \\
\text { data dari } \\
\text { mahasiswa yang } \\
\text { melakukan } \\
\text { pendaftaran } \\
\text { kerja praktek }\end{array}$ \\
\hline 2. & $\begin{array}{l}\text { Login sebagai } \\
\text { Dosen. }\end{array}$ & $\begin{array}{l}\text { Sistem akan } \\
\text { menampilkan } \\
\text { halaman dosen. } \\
\text { Dan } \\
\text { menampilkan } \\
\text { data mahasiswa } \\
\text { calon } \\
\text { pembimbing } \\
\text { kerja praktek } \\
\text { dari dosen yang } \\
\text { login }\end{array}$ & $\begin{array}{l}\text { Sistem } \\
\text { menampilkan } \\
\text { halaman dosen. } \\
\text { Dan } \\
\text { menampilkan } \\
\text { data mahasiswa } \\
\text { calon } \\
\text { pembimbing } \\
\text { kerja praktek } \\
\text { dari dosen yang } \\
\text { login }\end{array}$ \\
\hline
\end{tabular}




\section{KESIMPULAN DAN SARAN}

A. Kesimpulan

Berdasarkan hasil penelitian yang sudah dilakukan, maka dapat disimpulkan bahwa Aplikasi Website Administrasi Kerja Praktek dan Tugas Akhir Mahasiswa Program Studi Teknik Informatika UNSRAT telah berhasil dibangun dengan menggunakan metodologi pengembangan sistem RAD (Rapid Application Development). Pengembangan aplikasi web ini dilakukan dengan pendekatan MVC (Model View Controller) menggunakan framework PHP codeigniter.

Dengan memanfaatkan aplikasi web ini proses penandatanganan berkas Kerja Praktek dan Tugas Akhir Mahasiswa dapat dilakukan tanpa harus bertemu dengan dosen maupun pegawai sehingga proses adminstrasi kerja praktek dan tugas akhir menjadi yang lebih baik, lebih cepat dan mudah.

\section{B. Saran}

1. Aplikasi Website Administrasi Kerja Praktek dan Tugas Akhir Mahasiswa yang dibangun dalam jangka panjang dapat diintegrasikan dengan Sistem Informasi Akademik Fakultas Teknik Unsrat.

2. Aplikasi dapat dikembangkan dengan mengimplementasikan sebuah sistem SMS gateway pada fitur pesan masuk mahasiswa.

\section{DAFTAR PUSTAKA}

[1] Basuki, AP, 2010, Membangun Web Berbasis PHP dengan Framework Codeigniter. Lokomedia, Yogyakarta

[2] Handayaningrat, Soewarno. (1996). Pengantar Studi Ilmu Administrasi dan Manajemen. Jakarta : Hj Masagung.

[3] Jogiyanto, HM. 2005. Analisa dan Desain Sistem Informasi : Pendekatan TerstrukturTeori dan Praktek Aplikasi Bisnis. Andi, Yogyakarta.

[4] Kadir, Abdul. (2005). Dasar Pemrograman WEB dengan ASP. Andi, Yogyakarta.

[5] Madcoms. 2008. Teknik Mudah Membangun Website dengan HTML,PHP dan MySQL. Andi, Yogyakarta

[6] Peranginangin, Kasiman. 2006. Aplikasi WEB dengan PHP dan MySQL. Andi, Yogyakarta.

[7] Rosari, R. W. 2008. PHP dan MySQL untuk pemula, Andi, Yogyakarta.

[8] Tim Penyusun Buku Panduan Akademik Fakultas Teknik UNSRAT. 2015. Buku Panduan Akademik Fakultas Teknik Universitas Sam Ratulangi Manado
[9] Tim Pengembang Portal Resmi UNSRAT. 2015. Laporan Akhir RAD Pembangunan Portal Resmi Universitas Sam Ratulangi Manado

[10] Tim Penyusun Panduan Penulisan KTIS Fakultas Teknik UNSRAT. 2006. Panduan Penulisan Karya Tulis Ilmiah Sarjana (KTIS) Universitas Sam Ratulangi Manado Fakultas Teknik

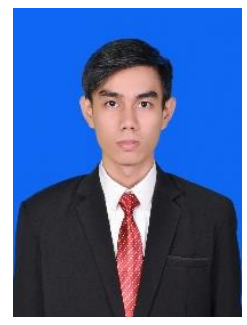

Sekilas dari penulis dengan nama lengkap Youri Janurady Basselo Toreh, lahir di Rantepao, Provinsi Sulawesi Selatan. Anak ke-4 dari 5 bersaudara. Dengan pendidikan Sekolah Dasar Negeri 70 Manado. Kemudian melanjutkan ke Sekolah Menengah Pertama Negeri 4 Manado. Kemudian melanjutkan ke Sekolah Menengah Kejuruan SMK N 1 Manado. Setelah lulus tahun 2011 melanjutkan ke Perguruan Tinggi di Universitas Sam Ratulangi dengan mengambil Jurusan Teknik Informatika. Pada Tahun 2015 bulan juli, penulis membuat Skripsi demi memenuhi syarat Sarjana (S1) dengan penelitian berjudul Rancang Bangun Aplikasi Website Administrasi Kerja Praktek dan Tugas Mahasiswa Program Studi Teknik Informatika Universitas Sam Ratulangi yang dibimbing oleh dua dosen pembimbing yaitu Dr. Eng Steven R. Sentinuwo, ST., MTI dan Alwin M. Sambul, ST., M.Eng., Ph.D sehingga pada tanggal 3 Oktober 2016 penulis resmi lulus di Teknik Informatika Universitas Sam Ratulangi Manado dan menyandang gelar Sarjana Komputer dengan predikat Sangat Memuaskan. 